\title{
Video Clubs: EFL Teachers' Selective Attention Before and After ${ }^{1}$
}

\author{
Eva Minaříková, Michaela Píšová, \\ Tomáš Janík, Klára Uličná \\ Masaryk University, Faculty of Education
}

\begin{abstract}
The paper aims to introduce results of a study of the effects of participation in video clubs on EFL (English as a Foreign Language) teachers' selective attention. It is a part of a larger project concerned with EFL teachers' professional vision. The paper introduces the theoretical background of study on teachers' professional vision and selective attention and the rationale of video clubs used specifically for EFL teachers. $11 \mathrm{EFL}$ teachers participated in this year-long study and attended video club meetings that aimed to foster their professional vision for conscious development of pupils' communicative competence. They were interviewed at the beginning and at the end of the programme; video sequences of their own teaching and of other teacher's teaching were used as prompts. The transcribed data were analysed using a theory-driven system of categories describing the areas of teachers' selective attention (i.e. aims, context, content, pupil/s, teacher, process). The results suggest that after participating in video clubs the teachers paid more attention to aims and content, and less to the teacher. The results for the category of pupil(s) differed for the own/other video sequence. As the development of communicative competence represents the ultimate goal of EFL teaching, it is encouraging that after the intervention the teachers' comments were more aim and content oriented.
\end{abstract}

Keywords: professional vision, selective attention, video in teacher education, video clubs, English as a foreign language, teacher education, teacher professional development

DOI: $10.14712 / 23363177.2015 .80$

It is a natural human characteristic that we do not attend to all the stimuli our senses can detect. This phenomenon is referred to as selective attention. In studies on professions and their characteristics, selective attention is often connected to the concept of professional vision which has been described by Goodwin as "socially organized ways of seeing and understanding events" (1994, p. 606). In teacher research, professional vision has been linked to teacher expertise (comp. Jacobs, Philipp, \& Sherin, 2011, p. xxv) and its changes to changes in teacher practices (van Es \& Sherin, 2010). There are numerous studies regarding its nature and development, mainly through the use of video in different formats (Borko et al., 2008; Brophy, 2004; Janík et al., 2009; Píšová, 2005). However, these studies and research projects focus mostly on the area of mathematics and science education (e.g. Sherin, Jacobs, \& Philipp, 2011). Teachers, however, are not a homogenous group and it is often pointed out that teachers of different subjects form so-called subcultures (Grossman, 1995). It has also been shown that the subjects the teachers

1 The preparation of this paper was supported by a Czech Science Foundation project GA13-21961S. 
56 teach influence their professional vision (Blomberg, Stürmer, \& Seidel, 2011). To fill the existing gap in research and our knowledge, our project focuses on the use of video for developing professional vision of in-service teachers of English as a foreign language (EFL), specifically in the context of video clubs. In this particular study we will focus on teachers' selective attention, i.e. what they pay attention to when commenting on classroom videos and if and how this changes after their participation in video clubs.

\section{Professional vision and selective attention}

When defining professional vision, two components are usually mentioned (Sherin, 2007, p. 384; Seidel et al., 2010, p. 297) - selective attention ${ }^{2}$ and knowledge-based reasoning. Selective attention can be defined as the process of identification of situations and events that are, from the professional point of view, instrumental for the success of pedagogical action (Seidel et al., 2010, p. 297). Knowledge-based reasoning represents the processes of making sense of situations and thinking about them, and presupposes certain knowledge (Seidel et al., 2010) or understanding (Sherin, 2007). These two components of professional vision are however interrelated and cyclical. Teachers direct their attention based on their reasoning and reason about things they give attention to (Sherin, Jacobs, \& Philipp, 2011, p. 5).

Selective attention refers to noticing certain phenomena in a classroom situation whilst not attending to others. In psychological terms, attending to means becoming aware of stimuli (e.g. Eysenck \& Keane, 1995, p. 95). Attention is paid only to salient stimuli while irrelevant information is discarded. Without this process, people would become overwhelmed with stimuli. In teacher research, studies of selective attention (noticing; comp. Sherin, Jacobs, \& Philipp, 2011, p. 5) differ. They vary in terms of whether they limit their scope to focus on a particular aspect of noticing (e.g. student thinking; Jacobs et al., 2011) or explore teachers' noticing in its entirety (e.g. Star et al., 2011). Studies also vary in their approach to investigating selective attention. Some of them adopt the exploratory (descriptive) stance by "letting teachers notice" events (usually by means of an interview or a discussion stimulated by a video recording ${ }^{3}$ ) and then analysing what has been addressed. On the other hand, some studies start by defining, based on previous research, what should be attended to and then check if and how teachers reason about these phenomena while not including other aspects (usually by means of a scale-based questionnaire; see for example Seidel et al., 2010, pp. 299-300).

2 The term noticing is sometimes used instead of selective attention. Some authors adopt, however, a broader definition of noticing that includes also knowledge-based reasoning processes (comp. Sherin, Jacobs, \& Philipp, 2011, p. 9). As we want to focus only on the "what" teachers notice, we shall use the term selective attention.

3 The mentioned methods belong to the most used. However, new approaches are being developed at the moment, such as the use of eyetracking for understanding teachers' visual processing of classroom situations (e.g. Wolff, 2014). 
As there is a lack of studies focusing on EFL teachers' selective attention, we adopt the exploratory approach and aim to investigate their noticing in its entirety. That is also why, for the purpose of this paper, we do not focus on knowledge-based reasoning and will address the issue elsewhere. We ask teachers to comment on classroom videos and then analyse their responses using broad categories describing the common themes in the study of teaching and learning (see below). On the other hand, in the intervention part of our study we adopt the "prescriptive" stance guiding the participants to notice specific features of the situations and reason about them. This approach is common in many pre-service and in-service teacher education programmes focusing on the development of professional vision and, what we consider particularly important, meets the ethical requirements posed on teacher research. To name a few examples of such interventions with different foci, Sherin and van Es (2009) focused on helping the teachers identify and interpret student ideas about mathematics, whereas Gold, Forster, and Holodynski (2013) focused on assisting pre-service teachers in noticing features of classroom situations salient for effective classroom management. The next chapter will introduce the structure of our intervention as well as its particular aim.

\section{Video clubs}

Our video clubs were inspired mainly by professional development programmes from the field of mathematics teacher education (video clubs, Problem Solving Cycle; see below). However, the focus was strictly domain-specific. As the main aim of English as a foreign language lessons and teaching is the development of pupils' communicative competence, the intervention focused on a specific aspect of EFL teachers' professional vision - the attention to conscious development of pupils' communicative competence. Communicative competence (see CEFR, 2001; Bachmann, 1990) has been the leading concept in EFL teaching since 1970s (Larsen-Freeman \& Freeman, 2008, Kumaravadivelu, 2006). It provides the goal for language learning and as such guides language teaching, provides framework for assessing pupils' progress and can also be used to evaluate instruction. This is why we believe EFL teachers should possess professional vision for development of pupils' communicative competence. This would allow them to plan instruction with relevant goals (professional vision in pre-active phase), see, attend to, and respond to situations appropriately (treatment of mistakes, approach to individual students, etc.) and be able to evaluate their own actions within this framework. Thus, a greater integration of instructional aims and content into teachers' considerations of teaching and learning was the aim of our intervention.

There are many models of communicative competence (e.g. Bachmann, 1990; Canale \& Swain, 1980; CEFR, 2001; Savignon, 1983). In our approach we draw on the conceptualization by Van Ek (1986) ${ }^{4}$ that posits that in order to develop learners'

4 We did not make use of the Common European Framework (CEFR) conceptualization as it guides the curricular documents in the Czech Republic and the teachers work with it on a daily basis. 
58 ability to communicate in a foreign language, we need not only to (a) teach vocabulary, grammar or pronunciation (linguistic competence), but also help the learners (b) to interpret and use the language forms appropriately to the situation (socio-linguistic competence), (c) to form coherent utterances and understand communication patterns (discourse competence), develop (d) their ability to compensate the gaps in their knowledge (strategic competence), and assist them in (e) getting acquainted with the socio-cultural context (socio-cultural competence). We should also not forget (f) to foster their overall ability to participate in social situations (social competence; see Van Ek, 1986, pp. 30-31). This model guided our intervention organized in the form of video clubs.

In order for the concept of communicative competence to become a part of teachers' professional knowledge (that drives professional vision), its integration into their knowledge structures through lived experience and its reflection was vital. That is why, besides the intervention being inspired by videoclubs (van Es \& Sherin, 2008), we also integrated some elements (activity design - see below) of the Problem Solving Cycle programme (Koellner et al., 2007). By a video club we mean a group of teachers (three or four) and facilitators from the university (two) that met regularly to discuss classroom videos. Each video club met five times throughout the year. Besides the meetings, the teachers were videotaped four times and had to complete given assignments. Each video club meeting lasted approximately 90 minutes. The facilitators were present and actively involved in the discussion. The meetings were videotaped and a voice recorder was used to capture quieter exchanges. As the groups were small (three to four participants), all the participants always worked together. Despite the common format (organized around watching classroom videos), each session was specific. The first meeting focussed mainly on breaking the ice among the participants and getting to know each other. Even though the teachers had been videotaped once before the first meeting, the videos used in this session did not depict any of the current participants but portrayed classroom video sequence from EFL lessons at different types of schools. The facilitators participated in the discussion but did not steer participants' attention in any way. During the second meeting, two video sequences (approx. 3-5 minutes) from participants' lessons were shown (selected by the facilitators in cooperation with the teachers in question). Gradually, the facilitators started asking questions about the aims and the content of the lesson. The session finished with a facilitator initiated discussion regarding communicative competence and activities and tasks that aid its development. For homework, the participants were asked to read a short handout on communicative competence and its components and different types of communicative and pre-communicative activities in EFL lessons (cf. Littlewood, 2004). At the start of the third meeting, the participants were asked for feedback and a short discussion ensued regarding the theoretical input. One of participant's videos was

We believed it could be perceived as criticism of their work. We thus chose Van Ek's approach that is related to CEFR, relatively simple and, in our opinion, easy to grasp, and relevant for learners' needs. 
then watched and discussed with facilitators steering attention again towards developing communicative competence. At the end of the session, the teachers were asked to design an activity together that would be communicative in nature and could be used in their classes. They were asked to use this activity in the following videotaped lesson in a version modified to the level of communicative competence of their learners as well as to the context (and provide a short written overview of changes they had to make in order to adapt the activity). Sequences depicting these activities were shown and analysed at the fourth meeting. The fifth meeting included discussions of more video sequences from participants' lessons with no specific focus and the whole video club experience was summarized. An overview of the structure of video clubs is shown in Figure 1.

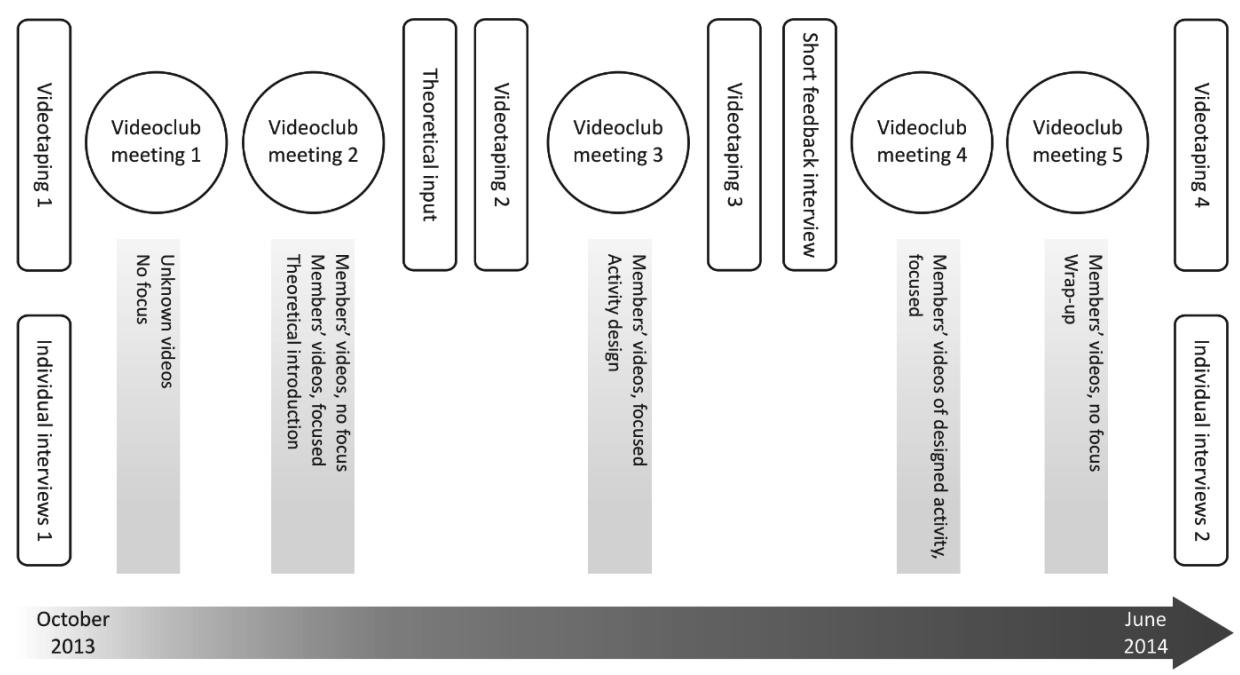

Figure 1 Video club design

There were altogether three groups of teachers participating in video clubs in 2013/2014. Two of them included teachers from different schools. In one group (B), some of the teachers had known each other beforehand, in the other (A) the teachers had never met. These video clubs took place at the university. The third group (school-based) comprised four colleagues from one school who had decided together that they would participate. The school provided premises where the video club was organized. 


\section{Research aims and questions}

In our research project we are concerned with EFL teachers' professional vision and the possibilities for its development through video clubs. In this particular study we focused on if and how selective attention (i.e. the "content" of professional vision) changes after teachers' participation in video clubs (that focused on the conscious development of pupils' communicative competence). The research questions are as follows:

Was there a difference in selective attention (i.e. a component of professional vision) when practising EFL teachers observed a video sequence of a classroom situation before and after their participation in video clubs?

- Was there a difference in the absolute occurrence of the individual categories of selective attention (see Section 4.3)?

- Was there a difference in the relative occurrence of the categories of selective attention (for individual teachers)?

\section{Methods}

\subsection{Participants}

This study is a part of a larger project. Within this project, the data was first collected through an online video-questionnaire based survey. Schools from the Southern Moravian region were randomly selected and contacted. In order to be included in the research sample, the teachers needed to be qualified to teach English as a foreign language ${ }^{5}$. When selecting participants for video clubs, convenience sampling was used. After the completion of the online questionnaire, all the teachers were offered to participate in video clubs. Eleven teachers agreed to take part and were divided into three groups that met throughout the year (see above). Table 1 gives detailed information about the research sample. Even though the original survey sample included teachers from around the Southern Moravia region, only teachers from Brno, where our research institution is based, participated in video clubs.

\subsection{Data collection}

The data was collected within the school year 2013/2014. Two individual interviews were conducted with each participant - one before the first video club meeting, the other after the last meeting. Each interview followed a videotaping of the participant's lesson and was based on two video sequences. The first one was a two and a half minute long sequence from a previous video study that depicted a situation from an EFL lesson (7th grade) where the teacher works with the whole class and

5 In the Czech context this means holding a Master's degree in teaching English at (lower) secondary schools or holding a Master's degree in teaching at primary schools with specialization in EFL. 
Table 1 Participants

\begin{tabular}{cccclcc}
\hline Teacher & School & Grade & $\begin{array}{c}\text { Years of } \\
\text { teaching } \\
\text { experience }\end{array}$ & $\begin{array}{c}\text { Qualified for } \\
\text { teaching }\end{array}$ & $\begin{array}{c}\text { Video } \\
\text { club }\end{array}$ & $\begin{array}{c}\text { Experience } \\
\text { with using } \\
\text { video in PD }\end{array}$ \\
\hline T1 & A & 5 & 9 & English + arts & B & No \\
T2 & B & 9 & 9 & English + chemistry & B & Yes \\
T3 & C & 3 & 4 & primary & A & Yes \\
T4 & D & 7 & 11 & English + Czech & B & No \\
T5 & E & 5 & 2 & primary & SB & No \\
T6 & E & 2 & 2 & primary & SB & Yes \\
T7 & F & 7 & 2 & English + Czech & A & No \\
T8 & G & 9 & 13 & English + Czech & B & No \\
T9 & H & 5 & 17 & English & A & No \\
T10 & E & 3 & 17 & English + special & SB & Yes \\
T11 & E & 7 & 1 & English & & Yes \\
\hline
\end{tabular}

elicits responses regarding the pictures in the textbook from the pupils. Both the teacher and the pupils are visible in the sequence. This video sequence was used in both the pre- and the post-interview (further on labelled as "other"). ${ }^{67}$

The second video sequence was selected from the videotaped lesson ${ }^{8}$ (further on labelled as "own"). Such sequences were chosen that showed interaction between the teacher and the pupils where both were visible and audible. If possible, instances of "genuine communication" were selected (rather than e.g. grammar exercises or drill sessions).

During the interview, the teachers watched each video sequence twice. First as a whole, then they took control and could stop it at any point. The opening task was "could you please comment on the video sequence". No further prompts were given. The interview continued until they stated they have nothing more to say. On average the interviews lasted about 30 minutes.

\subsection{Data analysis}

The data was analysed using a system of categories for describing selective attention derived from basic categories related to teaching and learning. These were: teacher, pupil(s), aims, content, process, and context (see Table 2). These are the main didactic categories covering the different aspects of teaching and learning (for Czech

6 Each teacher chose one class to have recorded which remained constant throughout the whole project. Grade refers to the grade of this class.

7 Professional development.

8 The videotaping and the interview usually took place on the same day. 
62 Table 2 System of categories for describing teachers' selective attention

\begin{tabular}{|c|c|c|}
\hline & Description & Example \\
\hline Teacher & $\begin{array}{l}\text { The statement focuses on the teacher } \\
\text { (in the video sequence) - his/her } \\
\text { actions, knowledge, thinking etc. }\end{array}$ & $\begin{array}{l}\text { I liked the way the teacher used gestures, } \\
\text { her demeanour; she seemed really nice to } \\
\text { me. I liked that. (T3_post_other) }\end{array}$ \\
\hline Pupil(s) & $\begin{array}{l}\text { The statement focuses on a pupil or } \\
\text { pupils (either in the video sequence, } \\
\text { in general or the respondents' own } \\
\text { pupils) - their actions, knowledge, } \\
\text { thinking etc. }\end{array}$ & $\begin{array}{l}\text { You can see the kids are already on } \\
\text { holiday, distracted. (T9_post_own) }\end{array}$ \\
\hline Aims & $\begin{array}{l}\text { The statement focuses on the aims, } \\
\text { either general aims of (language) } \\
\text { education or (supposed) aims of the } \\
\text { activities portrayed or aims intended by } \\
\text { the teacher in the video sequence. }\end{array}$ & $\begin{array}{l}\text { The activity was meant for the kids to } \\
\text { reinforce their knowledge of prepositions, } \\
\text { those basic ones. (T8_post_own) }\end{array}$ \\
\hline Content & $\begin{array}{l}\text { The statement focuses on the content } \\
\text { (to be learned). This includes English/ } \\
\text { Czech as a medium of instruction as in } \\
\text { language teaching the language used } \\
\text { provides (or does not provide) input for } \\
\text { the learners. }\end{array}$ & $\begin{array}{l}\text { Well, the English is quite..., sometimes } \\
\text { there is is instead of are, but anyway. } \\
\text { (T6_pre_own) }\end{array}$ \\
\hline Process & $\begin{array}{l}\text { The statement mentions the actions } \\
\text { being carried out - either with direct } \\
\text { connection to their agents or without it. }\end{array}$ & $\begin{array}{l}\text { And here she did the revision; quite } \\
\text { important and definitely valuable. } \\
\text { (T7_post_other) }\end{array}$ \\
\hline Context & $\begin{array}{l}\text { The statement includes a reference } \\
\text { to the context and conditions of the } \\
\text { situation, ranging from broad issues } \\
\text { (such as the state of society) to } \\
\text { classroom context (classroom layout and } \\
\text { equipment) and didactic media used } \\
\text { (textbook, whiteboard etc.). }\end{array}$ & $\begin{array}{l}\text { There was a map of England, or Great } \\
\text { Britain; that is a good teaching aid, too. } \\
\text { (T7_post_other) }\end{array}$ \\
\hline
\end{tabular}

didactic tradition see Skalková, 2007; for the continental tradition see for example Berliner Model - Heimann, Otto, \& Schulz, 1969). Referring to the perception of professional vision as a knowledge-based phenomenon, these categories represent dimensions of complex professional knowledge for teaching, their synergetic effect may be linked to what Shulman labelled as pedagogical content knowledge (1986, 1987; Kansanen, 2009). Compared to other studies of professional vision, resp. selective attention, there is close resemblance with the inductively created system of categories in the research by van Es and Sherin (2008): they identified two dimensions of the content of professional vision, the Actor (student, teacher, or other) and the Topic (mathematical thinking, pedagogy, climate, management, or other). Similarly, there are close links to the categories deployed in the research by Seidel et al. (2007).

First, the data from each participant were divided into four parts - comments on other video from pre-interview, comments on own video from pre-interview, com- 
ments on other video from post-interview, and comments on own video from post-interview. Afterwards, idea units, i.e. such parts of the comment that expressed one consistent and clearly separable idea (comp. van Es \& Sherin, 2006, p. 127; Jacobs \& Morita, 2002, p. 159) were identified in the comments. Further on we will call these idea units segments. Each segment was then assigned to one or more categories. We decided not to make the categories mutually exclusive as it has been shown by teacher knowledge research that teachers perceive classroom events and think about them in integrated patterns building on an organised knowledge base (Glaser \& Chi, 1988; Fenstermacher, 1994; Bransford et al., 2000, etc.). Therefore it was expected that while watching the sequences teachers will be able to activate these contextualised patterns (Putnam \& Borko, 2000; Seidel et al., 2011; Píšová \& Janík, 2011). Further on we shall call one occurrence of one category a code. Thus each part of an interview can be described by two numbers - the number of segments (ideas) and the number of codes (occurrences of categories). These are available in Table 3.

Table 3 Number of segments and codes in interview parts

\begin{tabular}{cccccc}
\hline Teacher & Video & Pre-Segments & Pre-Codes & Post-Segments & Post-Codes \\
\hline \multirow{2}{*}{ T1 } & own & 8 & 21 & 11 & 30 \\
& other & 7 & 19 & 5 & 12 \\
\hline \multirow{2}{*}{ T2 } & own & 20 & 45 & 7 & 21 \\
& other & 14 & 39 & 7 & 24 \\
\hline \multirow{2}{*}{ T3 } & own & 9 & 23 & 8 & 23 \\
& other & 12 & 26 & 8 & 22 \\
\hline \multirow{2}{*}{ T4 } & own & 11 & 32 & 26 & 87 \\
& other & 16 & 47 & 13 & 44 \\
\hline \multirow{2}{*}{ T5 } & own & 14 & 41 & 11 & 32 \\
& other & 9 & 24 & 4 & 10 \\
\hline \multirow{2}{*}{ T6 } & own & 11 & 22 & 11 & 28 \\
& other & 12 & 37 & 8 & 20 \\
\hline \multirow{2}{*}{ T7 } & own & 7 & 16 & 17 & 43 \\
& other & 7 & 20 & 15 & 28 \\
\hline \multirow{2}{*}{ T8 } & own & 27 & 79 & 18 & 50 \\
& other & 11 & 34 & 5 & 11 \\
\hline \multirow{2}{*}{ T1 } & own & 10 & 33 & 13 & 29 \\
& other & 21 & 51 & 10 & 30 \\
\hline \multirow{2}{*}{ Total } & own & 6 & 18 & 12 & 26 \\
\hline & other & 10 & 28 & 8 & 23 \\
\hline
\end{tabular}


The data was coded using MAXQDA software. Two researchers first fine-tuned their understanding of the category system by jointly coding 11 interview parts (pre_other). Afterwards, the intercoder agreement was checked on three interview parts. The coders agreed $80 \%$ of the time. Further discussions ensued to resolve disagreements. To ensure the greatest degree of objectivity, the rest of the data was coded jointly by the two researchers. The obtained numbers of codes were further analysed using statistical procedures (see below).

\section{Results}

This chapter will be structured according to the research questions. First, we will look at the overall difference in occurrence of categories (codes) before and after participation in video clubs, then at the difference between pre and post-interview for individual teachers. In each of these areas we will look at the results in general and also separately for the two conditions (other video vs. own video). However, it is not our aim here to investigate the differences between comments on the video of own teaching or another person's teaching (cf. Sherin \& van Es, 2009; Seidel et al., 2011). The purpose of using these two types of video was to investigate whether video club has the potential to change teachers' professional vision in its different manifestations. ${ }^{9}$

\subsection{Was there a difference in the absolute occurrence of the individual categories of selective attention?}

In order to respond to the first research question quantitative data analysis was deployed. Firstly, simple descriptive statistical analysis was conducted based on absolute occurrence of the categories identified in the interviews before and after the video clubs. Comparable values across the six categories are provided in Table 4, visualisation of the results in the form of a graph is offered for illustration in Figure 2.

Table 4 Total occurrence of the categories pre and post video clubs

\begin{tabular}{lccccccc}
\hline & Aim & Context & Content & Pupil(s) & Teacher & Process & Total \\
\hline pre & 13 & 51 & 102 & 175 & 146 & 205 & 692 \\
post & 31 & 63 & 130 & 168 & 84 & 169 & 645 \\
\hline
\end{tabular}

The analysis showed change in the occurrence of categories in teachers' comments on the observed video sequences before and after the video clubs: while the number of codes related to the categories of aims and content increased, there was a decrease of attention to the teacher and also to the procedural aspects of tuition.

9 Professional vision can be manifested in different contexts - when teachers observe other teachers' lessons, when they observe a videotape of their own teaching. Most importantly, it is manifested in the act of teaching itself. However, professional vision in action is difficult to research (comp. Sherin et al., 2008). 


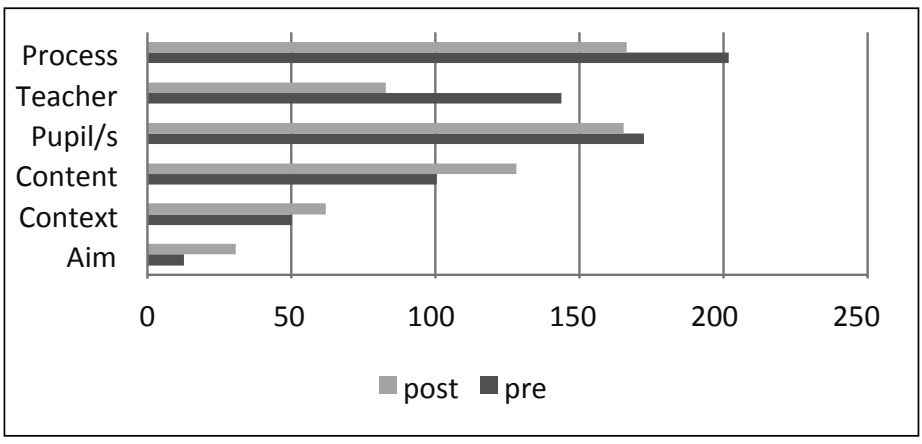

Figure 2 Total occurrence of the categories pre and post video clubs

The above analysis builds on overall data, i.e. on teachers' comments both on the video of own teaching and another person's teaching. Though we did not focus on the differences between them in this study, it was vital to find out whether the overall results were not influenced by the fact that both sets were included in the analysis. In other words, whether the above mentioned changes reflect differences in teachers' selective attention in general, no matter if watching own teaching performance or somebody else's. Further on, the results for comments on other and own video sequences before and after the video clubs are provided in the same format (number of occurrences; see Tables 5 and 6, Figures 3 and 4).

Table 5 Occurrence of categories in comments on other video sequence in pre- and post-interviews

\begin{tabular}{lccccccc}
\hline & Aim & Context & Content & Pupil/s & Teacher & Process & Total \\
\hline pre & 4 & 32 & 54 & 79 & 69 & 102 & 340 \\
post & 14 & 24 & 49 & 57 & 26 & 77 & 247 \\
\hline
\end{tabular}

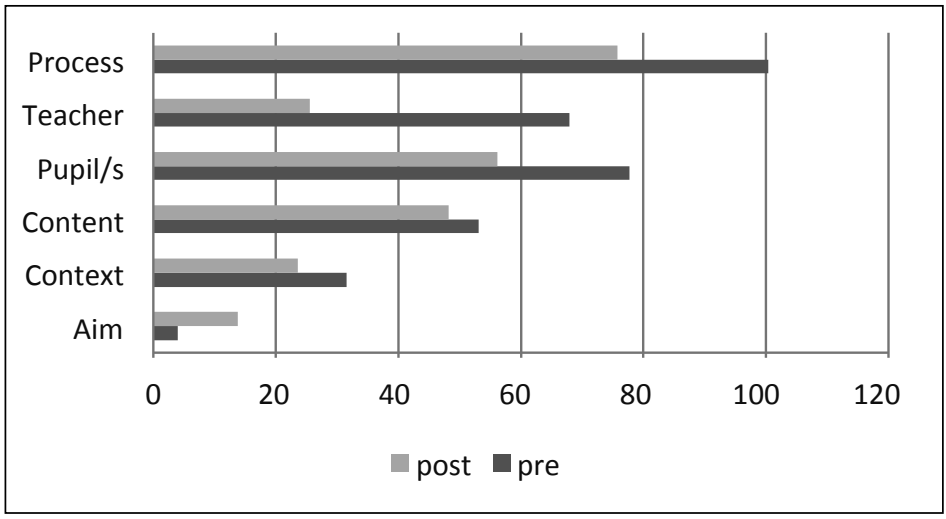

Figure 3 Occurrence of categories in comments on other video sequence in pre- and post-interview 
From Table 5 it is evident that in the comments on other video the absolute occurrence increased only in the category aim. Content and context were mentioned slightly less. The most prominent decrease is evident in categories process, pupil(s), and especially teacher.

Table 6 Occurrence of categories in comments on own video sequence pre and post video clubs

\begin{tabular}{lccccccc}
\hline & Aim & Context & Content & Pupil/s & Teacher & Process & Total \\
\hline pre & 9 & 19 & 48 & 96 & 77 & 103 & 352 \\
post & 17 & 39 & 81 & 111 & 58 & 92 & 398 \\
\hline
\end{tabular}

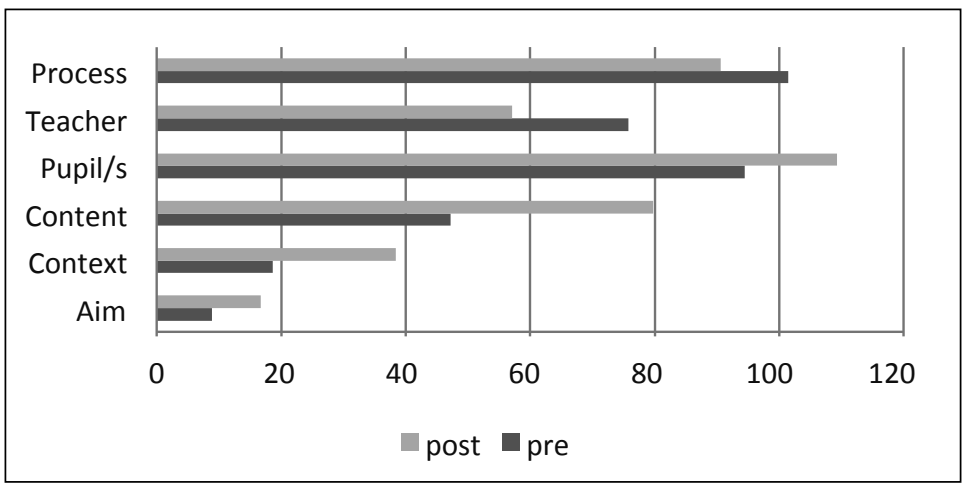

Figure 4 Occurrence of categories in comments on own video sequence in pre- and post- interviews

The results for the differences in the comments on one's own teaching performance show a slightly different picture. There was a decrease in the occurrence of two categories (process and teacher), and increase in all the other categories.

From Tables 5 and 6 it is obvious, that the overall number of codes decreased after the participation in video clubs. However, the decrease was more prominent in the other video comments. Thus we need to be careful when interpreting the results expressed by absolute numbers. In the next part, we are going to explore the results in relative numbers (percentages) - that is how much of participants' comments referred to the individual categories.

\subsection{Was there a difference in the relative occurrence of the categories of selective attention (for individual teachers)?}

There are more reasons for posing the second research question. Firstly, individual teacher developmental trajectories help us detect whether there were any extreme cases that would influence the overall results; that is, in a way, to validate the above response to the first research question. Secondly, we wanted to find out whether any groups of teachers in terms of how their professional vision, resp. selective attention, changed as a result of participation in the video clubs may be identified. This might 
indicate the procedural validity of video clubs; we find it especially important as the teachers are to a great extent the designers of the video clubs, their decisions and needs may strongly shape the content of discussion on the video sequences in their groups (see the description of video clubs in 2). It is important to learn whether any significant differences may be caused by the participation in a specific group. Last but not least, as it is planned to run the video clubs as a means for promoting (English language) teacher professional development as one of the Didactica Viva scheme activities, i.e. within the framework of pregraduate teacher education as well as CPD courses for practising teachers, a deeper insight into individual differences among teachers is a sine qua non.

Quantitative analysis was again considered appropriate as we search for the changes in the frequency of occurrence of comments in individual categories. However, as the focus is on individual teachers', relative occurrence of codes must be considered. Relative figures (percentages) stand for the proportions of attention individual teachers paid to individual categories while commenting on the video sequences. As the overall results indicated a distinction between selective attention when observing own or other video sequence in the category of pupil(s), the analysis was conducted separately for these two sets of data. Table 7 presents the results of the analysis, further visualisation is provided in Figures 5 and 6 in the form of radar charts.

When reading Table 7 vertically, the overall view of the columns with arrows indicating increase/decrease in individual categories as well as the graph shapes depicted in the graphic presentation of results in Figures 5 and $6{ }^{10}$ obviously correspond to the results obtained in the first analysis. Thus, they prove shifts in teachers' selective attention, namely higher frequency of occurrence of the categories of aims, as well as context and content balanced by the decrease in the categories of teacher and process. As regards the category of pupil(s), the difference in shifts between own and other video is also clearly visible.

As regards statistical significance of the changes we used the data from Table 7 to compare the results in the individual categories pre and post video clubs (see Table 8). Due to the nature of the data, we ran non-parametric Wilcoxon Signed Ranks Test. For the other video, there was a significant increase in the category of aims $(Z=-2.366, p<0.05)$ and significant decrease in the category of teacher $(Z=-2.934$, $\mathrm{p}<0.05)$. In the remaining categories minor changes can be observed, specifically an increase of attention to the category of content.

The test showed that the changes in the content of teachers' selective attention related to their own teaching were statistically significant in three categories: those of content $(Z=-2.134, p<0.05)$, teacher $(Z=-2.402, p<0.05)$, and process $(Z=-2.223, p<0.05)$. While the frequency of comments on content increased in a significant way, noticing of aspects of teacher performance and of instructional processes was significantly less represented after the video clubs. Minor tendencies in the sense of growing attention were observed in the categories of aims and pupil(s).

10 These graphs illustrate the changes. Their compact nature allows for viewing of the data from Table 7 in context of all participants and categories at a glance. Concrete numbers for individual participants are available in Table 7. 
๑ กี น้ก

$\leftarrow \uparrow \uparrow \leftarrow \leftarrow \rightarrow \uparrow \leftarrow \rightarrow \leftarrow \rightarrow \uparrow \leftarrow \leftarrow \leftarrow \uparrow \uparrow \uparrow \leftarrow \leftarrow \leftarrow \leftarrow$

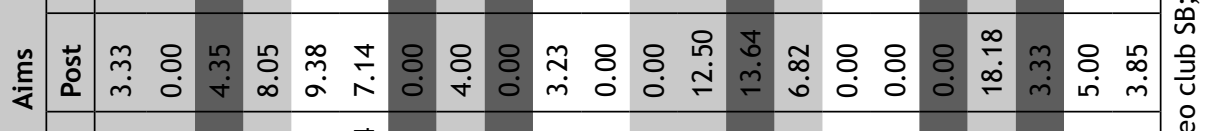
ஊ оәр!^ UMO 0әр!^ дәчт0

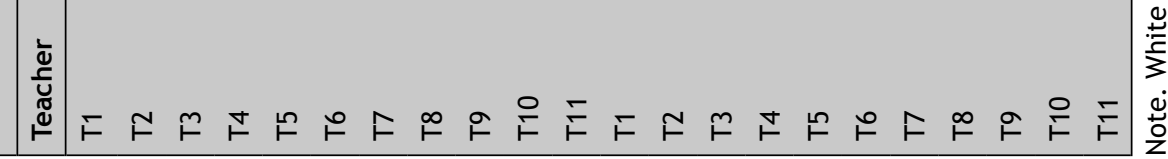




\section{Pre_other}

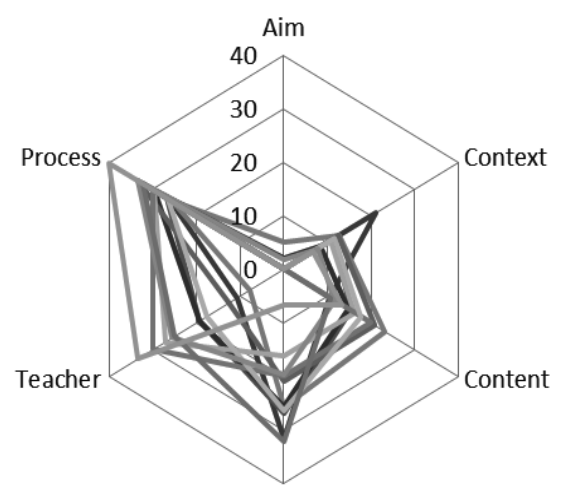

Pupil(s)

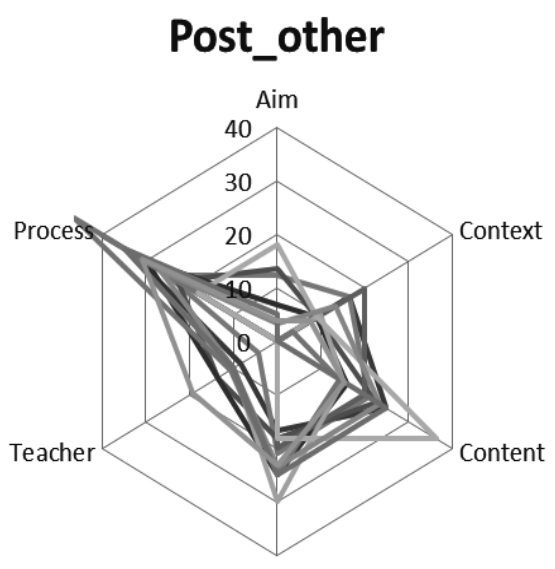

Pupil(s)

Figure 5 Relative occurrence of the individual categories in individual teachers' comments other video sequences in pre- and post-interviews

\section{Pre_own}

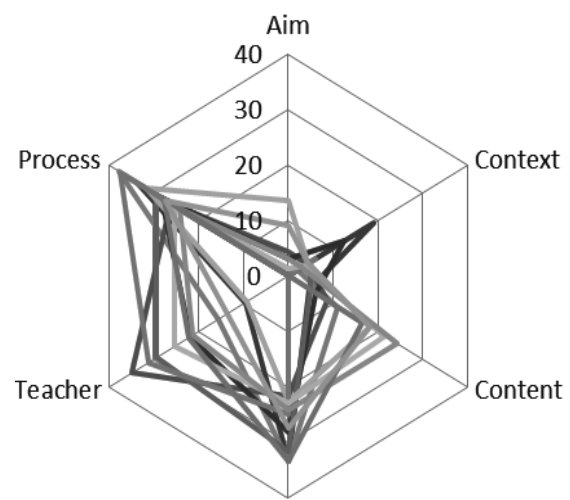

Pupil(s)
Post_own

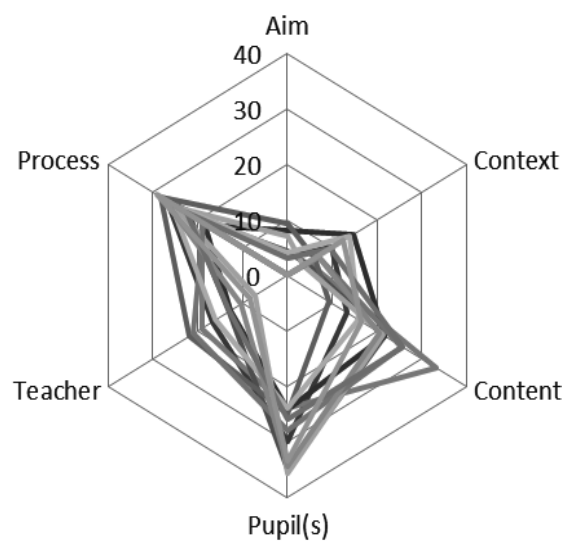

Figure 6 Relative occurrence of the individual categories in individual teachers' comments on their own video sequences in pre- and post-interviews 
70 Table 8 Comparison of relative occurrence of individual categories pre and post video clubs

\begin{tabular}{ccccccccc}
\hline & \multicolumn{9}{c}{ Own } & \multicolumn{5}{c}{ Other } \\
\hline & $\begin{array}{c}\text { Pre } \\
M(S D)\end{array}$ & $\begin{array}{c}\text { Post } \\
M(S D)\end{array}$ & $Z$ & $\begin{array}{c}\text { Asymp. } \\
\text { Sig. } \\
\text { (2-tailed) }\end{array}$ & $\begin{array}{c}\text { Pre } \\
M(S D)\end{array}$ & $\begin{array}{c}\text { Post } \\
M(S D)\end{array}$ & $Z$ & $\begin{array}{c}\text { Asymp. } \\
\text { Sig. } \\
\text { (2-tailed) }\end{array}$ \\
Aim & $3.14(4.47)$ & $3.59(3.44)$ & $-0.420 \mathrm{a}$ & 0.674 & $0.84(1.64)$ & $5.76(6.37)$ & $-2.366 \mathrm{a}$ & $0.018^{*}$ \\
Context & $5.93(5.34)$ & $8.54(3.96)$ & $-1.784 \mathrm{a}$ & 0.074 & $9.41(5.97)$ & $10.47(5.89)$ & $-0.866 \mathrm{a}$ & 0.386 \\
Content & $12.23(7.94)$ & $20.53(6.58)$ & $-2.134 \mathrm{a}$ & $0.033^{*}$ & $15.85(4.20)$ & $21.26(6.44)$ & $-1.600 \mathrm{a}$ & 0.110 \\
Pupil(s) & $27.60(4.64)$ & $29.00(4.81)$ & $-0.445 \mathrm{a}$ & 0.657 & $22.87(7.32)$ & $22.30(3.95)$ & $-0.445 \mathrm{~b}$ & 0.657 \\
Teacher & $21.25(8.61)$ & $14.45(4.91)$ & $-2.402 \mathrm{~b}$ & $0.016^{*}$ & $20.69(8.25)$ & $9.07(5.83)$ & $-2.934 \mathrm{~b}$ & $0.003^{*}$ \\
Process & $29.87(4.67)$ & $23.90(4.01)$ & $-2.223 \mathrm{~b}$ & $0.026^{*}$ & $30.33(4.24)$ & $31.15(8.04)$ & $-0.089 \mathrm{a}$ & 0.929 \\
\hline
\end{tabular}

Note. $\mathrm{a}$ - based on negative ranks; $\mathrm{b}$ - based on positive ranks. Asterisk denotes statistically significant results $(p<0.05)$.

These results in general correspond to the findings of the study by Seidel et al. (2011) who found some indication that the video observation may to a certain extent activate prior knowledge about teaching and learning in teachers, so that the viewing is enriched or affected. However, our analysis did not reveal dramatic differences between the orientation (increase - decrease) of changes in selective attention displayed before and after the video clubs when watching other or own video in any of the categories, it was rather the extent of the change that differed in the two sets of data. Thus, it may be concluded that the content of teachers' selective attention changed after participating in the video clubs, the occurrence of the categories of aims, content (and in a less obvious way also context) increased, while those of teacher and process decreased. No major change was identified in the category of pupil(s), though a more detailed look indicates that noticing here differed when watching other and own video sequences.

In interpreting the results, however, we were here concerned with the information provided when reading Table 7 vertically, or when analysing individual graphic representations of the shifts. The analysis proves that though the teachers shifted in what they noticed in slightly different ways, there were no extreme cases that would outbalance the overall results in one way or another. Furthermore, the analysis did not reveal any significant commonalities in the shifts of selective attention, the results do not indicate any differences that might result from one or more of the video club groups specificity. This finding may be interpreted as a sign of procedural validity of the video clubs. In all of them the same trends prevailed: the consistence of the shifts towards more attention to the categories of aims and content in teachers' selective attention. In terms of the objectives of video clubs, i.e. promoting professional vision for communicative competence development in pupils, this fact may be perceived as positive evidence.

It may be concluded that the response to the second research question to a certain extent triangulated the results obtained in the first analysis, and, in addition to 
that, confirmed some characteristics of teachers' selective attention development

identified in research on teachers mathematics (e.g. van Es \& Sherin, 2008), namely its individual character. In order to gain deeper insight into what teachers notice and how it may change in the video clubs, however, further analysis of the teachers' pre- and post-interviews aimed at the content of their comments (including their complex or integrated character) would be desirable.

\section{Discussion}

The presented study is a part of larger research focussing on EFL teachers' professional vision and its development. In this paper we focused on teachers' selective attention and how it changes after their participation in video clubs. In the video clubs we set out to develop a specific aspect of EFL teachers' professional vision, namely the attention to conscious development of pupils' communicative competence. During the intervention we not only aimed at developing their professional vision as such by directing their attention when observing classroom videos, we also aimed at their professional knowledge that strongly influences what is noticed and how. Van Ek's model of communicative competence was introduced as a part of the video club (declarative knowledge), and the participants were also provided with an opportunity to use it in collaborative lesson design, to implement it when teaching their own class, and to reflect on this experience.

Our study showed that participants' selective attention changed after video clubs. They tended to comment more on aims, content, and context, and less on processes and the teacher. These tendencies were evident in both types of comments, even though there were minor differences in the comments on own and other video (especially in the category pupils).

In the context of our intervention aim, these results seem encouraging. Our programme was aimed at helping the participants focus on the development of pupils' communicative competence as the overall aim of foreign language teaching. It is necessary to understand communicative competence as a general idea, the aim on the horizon. It might be perceived as distant (in terms of time) but is immediately relevant when planning instruction and delivering lessons as it guides the particular lesson and activity aims and content, and also the choice and structuring of processes (teaching methods, organization forms, etc.). The results thus suggest that the intervention was successful: the participants paid more attention to aims and content when commenting on classroom videos after video clubs.

There was also a decrease in the number of comments related to the teacher and their performance which is consistent with previous studies (e.g. Sherin \& van Es, 2009). Should we only consider the data related to participants' own videos, we might be able to explain this decrease by the novelty of the experience of seeing oneself on screen that wears off by the end of the programme. However, as the decrease is consistent across the other and own videos, we can conclude that there was 
72 indeed a significant shift in participants' attention away from the teacher towards content, aims, and context.

Our study was conducted in the context of EFL teachers' professional development. However, the findings correspond with previous research on developing teachers' professional vision in other domains (mainly mathematics education). It has been shown that pre-service and in-service professional development programmes have effect on teachers' professional vision, both in general (e.g. Star \& Strickland, 2008) and also when the intervention is targeted at a specific aspect of professional vision. An example of the latter is video clubs of Sherin and van Es (2009) that aimed to help teachers focus on students' ideas and student thinking. When the content of the pre and post video clubs interviews were compared, there were significant differences in terms of how much the teachers addressed students and mathematical thinking in their comments. The occurrence of these two categories increased significantly whereas less attention was paid to the teacher and to the atmosphere.

It has also been established that courses focussing on developing teachers' knowledge have positive effects on participants' professional vision (Stürmer et al., 2013a). Our video clubs combined both approaches - focus on the development of both professional vision and professional knowledge. From the results of our study, it would appear that the concept of communicative competence has been to a certain degree incorporated into participants' knowledge structures. This might have been facilitated by the fact that not only information about the concept was provided, but that an element of lived experience and its collaborative reflection was also included in the intervention. However, in order to confirm such a conclusion, a deeper insight into the comments within the content and aim categories is necessary.

Another limitation of the present study was the low number of participants and convenient sampling. For obvious reasons, only teachers interested in the intervention programme participated. In future studies, including a control group might be desirable.

Nevertheless, our data afford further analyses. First, an exploration of how the different categories describing selective attention are combined in teachers' comments and how this changes after video clubs is needed. This could shed more light on the success (or lack of thereof) of video clubs. As mentioned above, communicative competence that stood in the foreground of our intervention efforts is a unifying concept that connects our reasoning about aims, content, processes, and pupils. It would thus be interesting to find out whether the teachers comments showed more integration in terms of categories combinations.

When investigating professional vision, it is not only "what" teachers notice that is important, but also "how" they reason about classroom situations. The interviews need to be further analysed in terms of knowledge-based reasoning in order to determine the overall changes in participants' professional vision.

Even though there are many more questions yet to be answered, this paper attempted to open the issue of EFL teachers' professional vision and its development through video clubs, which is a topic that has not received much research attention yet. 


\section{References}

Bachman, L. F. (1990). Fundamental considerations in language testing. Oxford: Oxford University Press.

Blomber, G., Stürmer, K., \& Seidel, T. (2011). How pre-service teachers observe teaching on video: Effects of viewers teaching subjects and the subject of the video. Teaching and Teacher Education, 27(7), 1131-1140 .

Bransford, J. D., Brown, A. L., \& Cocking, R. R. (Eds). (2000). How people learn: Brain, mind, experience and school. Washington, D. C.: National Academy Press.

Borko, H., Jacobs, J., Eiteljorg, E., \& Pittman, M. E. (2008). Video as a tool for fostering productive discussions in mathematics professional development. Teaching and Teacher Education, 24(2), 417-436.

Brophy, J. (Ed.). (2004). Using video in teacher education. Oxford: Elsevier.

Canale, M., \& Swain, M. (1980). Theoretical bases of communicative approaches to second language teaching and testing. Applied Linguistics, 1, 1-47.

Common European framework of reference for languages: learning, teaching, assessment. (2001). Cambridge: Cambridge University Press.

Eysenck, M. W., \& Keane, M. T. (1995). Cognitive psychology. A student's handbook. Hove: Psychology Press.

Fenstermacher, G. D. (1994). The knower and the known: The nature of knowledge in research on teaching. In L. Darling-Hammond (Ed.), Review of research in education, 20 (pp. 3-56). Washington: American Educational Research Association.

Glaser, R. , \& Chi, M. T. (1988). Overview. In M. T. Chi, R. Glaser, \& M. J. Farr (Eds.), The nature of expertise (pp. xv-xxviii). Hillsdale: Erlbaum.

Gold, B., Förster, S., \& Holodynski, M. (2013). Evaluation eines videobasierten Trainingsseminars zur Förderung der professionellen Wahrnehmung von Klassenführung im Grundschulunterricht. Zeitschrift für pädagogische Psychologie, 27(3), 141-155.

Goodwin, C. (1994). Professional vision. American Anthropologist, 96(3), 606-633.

Grossman, P. (1995). Content as context: The role of school subjects in secondary school teaching. Educational Researcher, 24(8), 5-23.

Heimann, P., Otto, G., \& Schulz, W. (1969). Unterricht, Analyse und Planung. Hannover: Schroedel.

Jacobs, J. K., \& Morita, E. (2002). Japanese and American teachers' evaluations of videotaped mathematics lessons. Journal for Research in Mathematics Education, 33(3), 154-175.

Jacobs, V., Philipp, R., \& Sherin, M. (2011). Preface. In M. G. Sherin, V. R. Jacobs, \& R. A. Philipp (Eds.), Mathmatics teacher noticing. Seeing through teachers' eyes (pp. xxvxxvii). New York: Routledge.

Janík, T., Janíková, M., Knecht, P., Kubiatko, M., Najvar, P., Najvarová, V., \& Šebestová, S. (2009). Exploring different ways of using video in teacher education: Examples from CPV Video Web. In T. Janík, \& T. Seidel (Eds.), The power of video studies in investigating teaching and learning in classroom (pp. 207-224). Münster: Waxmann Verlag.

Kansanen, P. (2009). The curious affair of pedagogical content knowledge. Orbis scholae, $3(2), 5-18$.

Koellner, K., Jacobs, J., Borko, H., Schneider, C., Pittman, M. E., Eiteljorg, E., Bunning, K., \& Frykholm, J. (2007). The Problem-Solving Cycle: A model to support the development of teachers' professional knowledge. Mathematical Thinking and Learning, 9(3), 273-303.

Kumaravadivelu, B. (2006). Understanding language teaching: From method to postmethod. Mahwah: Lawrence Erlbaum.

Larsen-Freeman, D., \& Freeman, D. (2008). Language moves: The place of "foreign" languages in classroom teaching and learning. Review of Research in Education, 32, 147-186.

Littlewood, W. (2004). The task-based approach: some questions and suggestions. ELT Journal, 58(4), 319-326. 
74 Píšová, M. (2005). Klinický rok: procesy profesního rozvoje studentů učitelství a jejich podpora [Clinical year: professional development processes in student teachers and their support]. Pardubice: Univerzita Pardubice, Fakulta humanitních studií.

Píšová, M., \& Janík, T. (2011). On the nature of expert teacher knowledge. Orbis Scholae, 5(2), 95-115.

Putnam, R. T., \& Borko, H. (2000). What do new views of knowledge and thinking have to say about research on teacher learning? Educational Researcher, 29(1), 4-15.

Savignon, S. J. (1983). Communicative competence: theory and classroom practice; texts and contexts in second language learning. Reading: Addison-Wesley.

Seidel, T., Blomberg, G., \& Stürmer, K. (2010). OBSERVE - Validierung eines videobasierten Instruments zur Erfassung der professionellen Wahrnehmung von Unterricht. Zeitschrift für Pädagogik, 56(Beiheft), 296-306.

Seidel, T., Stürmer, K., Blomberg, G., Kobarg, M., \& Schwindt, K. (2011). Teacher learning from analysis of videotaped classroom situations: Does it make a difference whether teachers observe their own teaching or that of others? Teaching and Teacher Education, 27(2), 259-267.

Sherin, M. G. (2007). The development of teachers' professional vision in video clubs. In R. Goldman, R. Pea, B. Barron, \& S. J. Derry (Eds.), Video research in the learning sciences (pp. 383-396). London: Lawrence Erlbaum Associates Publishers.

Sherin, M. G., Jacobs, V. R., \& Philipp, R. A. (Eds.). (2011). Mathmatics teacher noticing. Seeing through teachers' eyes. New York: Routledge.

Sherin, M. G., Jacobs, V. R., \& Philipp, R. A. (2011). Situating the study of teacher noticing. In M. G. Sherin, V. R. Jacobs, \& R. A. Philipp (Eds.), Mathmatics teacher noticing. Seeing through teachers' eyes (pp. 3-13). New York: Routledge.

Sherin, M. G., Russ, R. S., Sherin, B. L., \& Colestock, A. (2008). Professional vision in action: An exploratory study. Issues in Teacher Education, 17(2), 27-46.

Sherin, M. G. , \& van Es, E. A. (2009). Effects of video club participation on teachers' professional vision. Journal of Teacher Education, 60(1), 20-37.

Shulman, L. S. (1986). Those who understand: Knowledge growth in teaching. Educational Researcher, 15(2), 4-14.

Shulman, L. S. (1987). Knowledge and teaching: Foundations of the new reform. Harvard Educational Review, 57(1), 1-22.

Star, J. R., Lynch, K., \& Perova, N. (2011). Using video to improve preservice mathematics teachers' abilities to attend to classroom features: A replication study. In M. G. Sherin, V. R. Jacobs, \& R. A. Philipp (Eds.), Mathmatics teacher noticing. Seeing through teachers' eyes (pp. 117-133). New York: Routledge.

Star, J. R., \& Strickland, S. K. (2008). Learning to observe: Using video to improve preservice mathematics teachers ability to notice. Journal of Mathematics Teacher Education, 11(2), 107-125

Stürmer, K., Könings, K. D., \& Seidel, T. (2013). Declarative knowledge and professional vision in teacher education: Effect of courses in teaching and learning. British Journal of Educational Psychology, 83(3), 467-483.

Van Ek, J. A. (1986). Objectives for foreign language learning. Strasbourg: Council of Europe. Available from http://www.coe.int/t/dg4/linguistic/source/sourcepublications/scope _vanek_en.doc

van Es, E. A., \& Sherin, M. G. (2006). How different video club designs support teachers in "learning to notice". Journal of Computing in Teacher Education, 22(4), 125-135.

van Es, E. A., \& Sherin, M. G. (2008). Mathematics teachers' "learning to notice" in the context of a video club. Teaching and Teacher Education, 24(2), 244-276.

van Es, E. A., \& Sherin, M. G. (2010). The influence of video clubs on teachers' thinking and practice. Journal of Mathematics Teacher Education, 113(2), 55-176.

Wolff, C. E. (2014, June). Teachers' processing of problematic classroom situations. Paper presented at the EARLI SIG 11 conference, Frauenchiemsee, Germany. 
Institute for Research in School Education, Faculty of Education, Masaryk University Poříći 31, 60300 Brno, Czech Republic minarikova@ped.muni.cz

Michaela Píšová Institute for Research in School Education, Faculty of Education, Masaryk University Poříći 31, 60300 Brno, Czech Republic pisova@ped.muni.cz

Tomáš Janík Institute for Research in School Education, Faculty of Education, Masaryk University Poříći 31, 60300 Brno, Czech Republic tjanik@ped.muni.cz

Klára Uličná Institute for Research in School Education, Faculty of Education, Masaryk University Poříći 31, 60300 Brno, Czech Republic klara.ulicna@pedf.cuni.cz 